Grace PA, Pitt HA, Tompkins RK, DenBesten L, Longmire WP. Decreased morbidity and Condenectomy. Am f Surg 1986;151:141-9.

6 Crist DW, Sitzmann JV, Cameron JL. Improved hospital morbidity, mortality and survival after the Whipple procedure. Ann Surg 1987;206:358-65.

Trede M, Schwall G. The complications of pancreatectomy. Ann Surg 1988;207:39-47.

Warshaw AL, Swanson RS. Pancreatic cancer in 1988. Possibilities and probabilities. Ann Surg 1988;208:541-53.

9 Go VLW, Taylor WF, DiMagno EP. Efforts at early diagnosis of pancreatic cancer: the Mayo Clinic experience. Cancer 1981;47:1698-703.

10 Moossa AR, Levin B. The diagnosis of "early" pancreatic cancer: the University of Chicago experience. Cancer 1981;47:1688-97.

11 Campbell JP, Wilson SR. Pancreatic neoplasms: how useful is evaluation with ultrasound. Radiology 1988;167:341-4

12 Freeney PC, Marks WM, Ryan JA, Traverso LW. Pancreatic ductal adenocarcinoma-diagnosis and staging with dynamic CT. Radiologv 1988;166:125-33.

13 Ross CB, Sharp KW, Kaufman AJ, Andrews T, Williams LF. Efficacy of computed tomography in the preoperative staging of pancreatic carcinoma. Am Surg 1988;54:221-6.

14 Savarino V, Mansi C, Bistolfi L, Zentilin P, Celle G. Failure of new diagnostic aids in improving detection of pancreatic cancer at a resectable stage. Dig Dis Sci 1983;28:1078-82.

15 Paivansalo $M$, Lahde S. Ultrasonography and computed tomography in pancreatic malignancy. Acta Radiol 1988;29:343-4

16 Plainfosse MC, Bouillot JL, Rivaton F, Vaucamps P, Hernigou A, Alexandre JH. The use of operative sonography in carcinoma of the pancreas. World I Surg 1987;11:654-8.

17 Yasuda K, Mukai H, Fujimoto S, Nakajima M, Kawai K. The diagnosis of pancreatic cancer by endoscopic ultrasonography. Gastrointest Endosc 1988;34:1-8.

18 Sawada Y, Gonda H, Hayashida Y. Combined use of brushing cytology and endoscopic retrograde pancreatography for the early detection of pancreatic cancer. Acta Cytol 1989;33:870-4.

19 Steiner E, Stark DD, Hahn PF, et al. Imaging of pancreatic neoplasms-comparison of MR and CT. $A f R$ 1989:152:487-92.

20 Warshaw AL, Rutledge PL. Cystic tumours mistaken for pancreatic pseudocysts. Ann Surg 1987:205:393-8

21 Johnson CD, Stephens DH, Charboneau JW, Carpenter HA, Welch TJ. Cystic pancreatic tumours: CT and sonographic assessment. $A f R$ 1988;151:1133-8.

$22 \mathrm{Hart}$ MJ, White TT, Brown PC. Freeney PC. Potentially curable masses in the pancreas. Am $\mathcal{J}$ Surg 1987;154:134-6.

23 Boyd EJS, Rinderknecht H, Wormsley KG. Laboratory tests in the diagnosis of the chronic pancreatitic diseases. Part 6 . Differentiation between chronic pancreatitis and pancreatic cancer. Int $\mathcal{F}$ Pancreatol 1988;3:229-40

24 Ichihara T, Nakao A, Sakamoto J, et al. Application of the immunoperoxidase for rapid intraoperative pathological diagnosis of pancreatic cancer. I Surg Oncol 1988;40:8-16.

$25 \mathrm{~K}$ line TS, Lalita P, Goldstein F. Preoperative diagnosis of pancreatic malignancy by the cytologic examination of duodenal secretions. Am $\mathcal{F}$ Clin Pathol 1978;70:851-4.

26 Hewett PJ, Le Langlois S, Orell SR. Alimentary tract and pancreas. The diagnosis of mass lesions in the pancreas by fine needle aspiration biopsy. Fournal of Gastroenterology and Hepatology 1987;3:71-6.

27 Lees WR, Heron CW. US-guided percutaneous pancreatography: experience in 75 patients. Radiologr 1987;165:809-14

28 Oland J, Rosen A, Reif R, Sayfan J, Kent V, Orda R. Fine needle aspiration cytology of the pancreas. I Surg Oncol 1988;38:14-5

29 Al-Kaisi N, Siegler EE. Fine needle aspiration cytology of the pancreas. Acta Cytol 1989;33:145-52.

30 Soudah B, Fritsch RS, Wittekind C. Hilka B, Spindler B. Value of the cytologic analysis of fine needle aspiration biopsy specimens in the diagnosis of pancreatic carcinomas. Acta Cytol 1989;33:875-80.

31 Hall-Craggs MA, Lees WR. Fine needle biopsy-cytology, histology or both? Gut 1987;28:233-6.

32 Lin J-T, Wang T-H, Chen D-S, et al. Pancreatic carcinoma associated with chronic calcifying pancreatitis in Taiwan: a case report and review of the literature. Pancreas 1988;3:111.

33 Gambill EE. Pancreatitis associated with pancreatic carcinoma: a study of 26 cases. Mayo Clin Proc $1971 ; 46: 174-7$

34 Nieman JL, Holmes FF. Accuracy of diagnosis of pancreatic cancer decreases with increasing age. f Am Geriatr Soc 1989:37:97-100.

35 Ching CK, Rhodes JM. Identification and partial characterization of a new pancreatic cancerrelated serum glvcoprotein by sodium dodecyl sulfate-polvacrvlamide gel electrophoresis and lectin blotting. Gastroenterolog, 1988:95:137-42.

36 Metzgar RS, Asch HL. Antigens of human pancreatic adenocarcinomas: their role in diagnosis and therapv. December 7-8, 1987, Rockville, MD. Conference report. Pancreas 1988;3:352.

37 Opocher E, Spina GP, Santambrogio R, et al. Diagnosis of pancreatic cancer using DUPAN-2 monoclonal antibody. HPB Surgery 1990;2 (suppl):483

38 Nishida K, Tasaki N, Miyagawa H, Yoshikawa T, Kondo M. Estimation of carbohydrate antigen CA) $19-9$ levels in pure pancreatic juice of the patients with pancreatic cancer. Am $\mathcal{F}$ Gastroenterol 1988;83:126-9

39 Richter JM, Christensen MR, Rustgi AK, Silverstein MD. The clinical utility of CA19-9 radioimmunoassay for the diagnosis of pancreatic cancer presenting as pain or weight loss. Arch Intern Med 1989;149:2292-7

to Dunn PM, McKinstry M. CA19-9 and pancreatic cancer. Ann Intern Med 1989;111:343.

41 Fabris C, Del Favero G, Basso D, et al. Serum markers and clinical data in diagnosing pancreatic cancer: a contrastive approach. Am $\mathcal{f}$ Gastroenterol 1988;83:549-53.

42 Nardone DA. The serologic marker CA 19-9 and pancreatic cancer. Ann Intern Med 1989;111: $184-5$

\section{Justice versus equity for haemophiliacs with AIDS}

\section{Settling the claim would not set a precedent}

Haemophiliacs infected with HIV from contaminated blood products have won their Court of Appeal battle for access to government documents crucial to their case. The Department of Health had argued that the papers, which reveal government decisions on the supply of blood products, were protected from disclosure by public interest immunity. But the Appeal Court ruled that this was outweighed by the haemophiliacs' right to a fair trial of their claim.
Most of the 962 claimants are haemophiliacs who became infected with the virus from blood products. Of those, 50 have AIDS and 326 AIDS related complex. The families of 76 who have died are suing on their behalf. The plaintiffs also include 177 wives and children of haemophiliacs, of whom 23 are infected, one has AIDS, and 11 have AIDS related complex. Most of the haemophiliacs were infected by factor VIII imported from America, but some contracted the virus from British made factor VIII or factor IX. They claim that the government was negligent and in breach of its statutory duty under the National Health Service Act 1977 in not producing sufficient blood products in Britain to meet their needs. They also allege that the department was at fault in not screening out high risk donors and in not heat treating blood products sooner to kill viruses.

The haemophiliacs have surmounted a substantial hurdle in gaining access to the papers. But they will face more daunting obstacles when the case comes to trial next March. The Appeal Court judges doubted their chances of proving the department in breach of its duty under the NHS act, given the wording of the act. On their alternative claim, negligence, Lord Justice Bingham pointed out that this was difficult to prove against a public body that was required to exercise discretion and form judgments about the allocation of public resources.

This is, no doubt, the advice that the health secretary, Kenneth Clarke, has received from government lawyers. The tragedy, he insists, was "no one's fault." Yet, in the words of Lord Justice Bingham, on the case pleaded by the plaintiffs, "grave errors of judgment were made." From 1975 onwards ministers resolved to make Britain self sufficient in blood products but failed to do so, although it was widely known that factor VIII produced in the United States carried a substantial risk of infection with hepatitis B virus. In 1983 the department received advice from the United States that blood donors should be asked specific questions designed to screen out high risk donors. Instead, it issued a leaflet asking those at risk not to give blood. Routine testing for HIV was not started until October 1985, although tests were available in late 1984. Heat treatment was not introduced until April 1985.

Senior officials will face an embarrassing public cross examination when the case reaches trial next March. Sir Donald Acheson, the chief medical officer, has, according to well informed sources, urged $\mathrm{Mr}$ Clarke to settle the claims out of court. Even the judge in the case, Mr Justice Ognall, suggested that it should not go to trial. Win or lose, huge legal costs on both sides will have to be met by the taxpayer as most of the claimants have been granted legal aid.

$\mathrm{Mr}$ Clarke insists, "It would have very grave consequences for medicine in this country if compensation was paid whenever a patient who had been treated properly by his or her doctors later suffered awful side effects or died." The NHS, he maintains, would "become like the American system, where every doctor has a lawyer, and everybody pays huge compensation every time a treatment fails." Yet health authorities regularly settle small "nuisance value" claims when they believe that they were not at fault but the cost of fighting the claim makes it cheaper to settle.

Settling the haemophiliacs' claim would be expensive. But an out of court settlement without admission of liability would set no legal precedent. And a tragedy like the haemophiliacs' must be a rare occurrence. "The tragedy was avoidable," said Lord Justice Bingham, "in the sense that, had different measures been taken in the 1970s and early 1980s, it could, at least in large measure, have been prevented." Legally, the government may not be bound to pay. Morally, it should.

Legal correspondent, $B M \mathcal{F}$ 